\title{
Pure Mg-Al Layered Double Hydroxide Film on Magnesium Alloys for Orthopedic Applications
}

\author{
Shi Cheng, Lvqin Lan, Mei Li, Xiao Chu, Hua Zhong,* Mengyu Yao, Feng Peng,* and Yu Zhang* \\ Cite This: ACS Omega 2021, 6, 24575-24584 \\ Read Online
}

ABSTRACT: $\mathrm{Mg}$ alloys are promising biodegradable orthopedic implants in the future. However, poor corrosion resistance and biocompatibility limit their wide applications. In this study, a pure $\mathrm{Mg}-\mathrm{Al}$ layered double hydroxide (Mg-Al LDH) film on AZ31 was prepared through combining hydrofluoric acid pretreatment and hydrothermal treatment. Electrochemical analysis and the immersion test suggested that the as-prepared $\mathrm{Mg}-\mathrm{Al} \mathrm{LDH}$-coated sample exhibited significantly enhanced corrosion resistance. The in vitro cell culture revealed that the $\mathrm{Mg}-\mathrm{Al} \mathrm{LDH}$ film was favorable for the alkaline phosphatase activity, collagen secretion, and osteogenesis-related gene expression of MC3T3-E1. Furthermore, the LDH-coated sample was beneficial for the migration, vascular endothelial growth factor secretion, and angiogenesisrelated gene expression of human umbilical vein endothelial cells. The subcutaneous implantation test demonstrated that the $\mathrm{Mg}-\mathrm{Al} \mathrm{LDH}$ film could

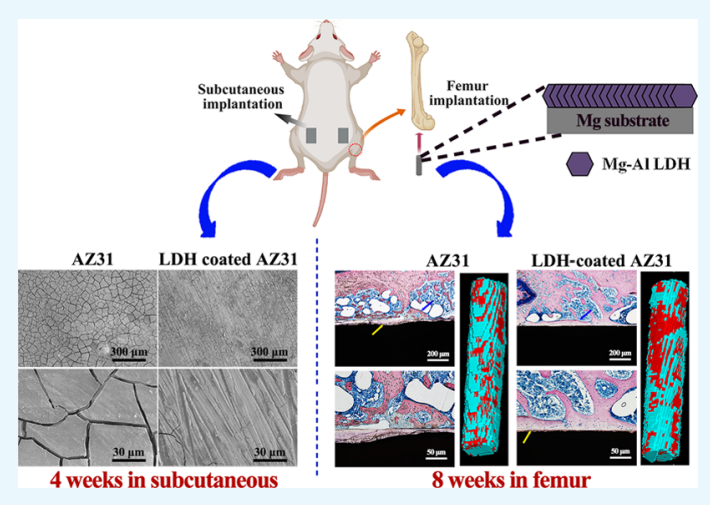
protect the substrate from corrosion and induce milder inflammation. The femur implantation demonstrated that the $\mathrm{Mg}-\mathrm{Al} \mathrm{LDH}$ sample showed better bone regeneration and osseointegration than bare AZ31. In summary, the as-prepared pure $\mathrm{Mg}-\mathrm{Al} \mathrm{LDH}$ film is able to enhance the in vitro and in vivo performances of $\mathrm{AZ31}$, indicating a promising application in the orthopedic field.

\section{INTRODUCTION}

$\mathrm{Mg}$ alloys are widely used in various fields such as the automotive industry, electronic products, aerospace industry, and biomedical implants because of their exceptional properties such as low density, good electromagnetic shielding characteristics, high damping capacity, high rigidity, and biodegradability. ${ }^{1-3}$ However, the low electrochemical potential of $\mathrm{Mg}$ alloys results in poor corrosion resistance, which inhibits their large-scale applications, especially in the biomedical field. The fast corrosion of $\mathrm{Mg}$ implants leads to the formation of gas cavity, loss of mechanical support, acute inflammatory reaction, and so on. ${ }^{4-6}$

Layered double hydroxides (LDHs) have received increased attention for their facile fabrication and effective corrosion protection in the past decade. ${ }^{7}$ The LDHs, also known as anionic clay or hydrotalcite, are composed of positively charged brucite-like layers and a negatively charged interlayer region. Their chemical formula is $\left[\mathrm{M}^{2+}{ }_{1-\mathrm{X}} \mathrm{M}^{3+} x(\mathrm{OH})_{2}\right]\left[\mathrm{A}^{n-}\right]_{x / n}$. $z \mathrm{H}_{2} \mathrm{O}$, where $\mathrm{M}^{2+}$ represents bivalent cations, such as $\mathrm{Mg}^{2+}$, $\mathrm{Zn}^{2+}$, or $\mathrm{Ni}^{2+}$, and $\mathrm{M}^{3+}$ represents trivalent cations such as $\mathrm{Al}^{3+}$, $\mathrm{Fe}^{3+}$, or $\mathrm{Mn}^{3+} .9,9$ Owing to the tunable structure of LDHs, many different types of $\mathrm{LDHs}(\mathrm{Mg}-\mathrm{Al}, \mathrm{Mg}-\mathrm{Fe}, \mathrm{Mg}-\mathrm{Cr}, \mathrm{Ni}-$ $\mathrm{Al}$, and $\mathrm{Zn}-\mathrm{Al})$ containing various interlayer anions $\left(\mathrm{NO}_{3}{ }^{-}\right.$, $\mathrm{CO}_{3}{ }^{2-}, \mathrm{Cl}^{-}$, and $\mathrm{VO}_{3}{ }^{-}$) were fabricated on the surface of $\mathrm{Mg}$ alloys via hydrothermal treatment. ${ }^{10-16}$ In some of these studies, not only the corrosion resistance was evaluated, but also the biocompatibility of the LDH films was investigated.
For example, Lin et al. found that human mesenchymal stem cells exhibited better spreading and proliferation on a $\mathrm{Mg}-\mathrm{Fe}$ LDH-coated Mg substrate. ${ }^{11}$ Among these different types of $\mathrm{LDH}$ films, $\mathrm{Mg}-\mathrm{Al} \mathrm{LDH}$ has been the widest studied owing to its easy fabrication. Researchers have investigated the influence of the $\mathrm{pH}$ value, reaction temperature, and substrate microstructure on the formation of the $\mathrm{Mg}-\mathrm{Al} \mathrm{LDH}$ film and the corresponding corrosion resistance. ${ }^{17-19}$ In addition, new methods (mainly steam coating) and pretreatment (mainly anodic oxidation) were also proposed to prepare the $\mathrm{Mg}-\mathrm{Al} \mathrm{LDH}$ film on $\mathrm{Mg}$ alloys. ${ }^{20-23}$ Although these studies were devoted to prepare a pure $\mathrm{Mg}-\mathrm{Al} \mathrm{LDH}$ film on $\mathrm{Mg}$ alloys, almost all the prepared $\mathrm{Mg}-\mathrm{Al} \mathrm{LDH}$ films were mixed with a $\mathrm{Mg}(\mathrm{OH})_{2}$ phase, which can be ascribed to the fast release of $\mathrm{Mg}^{2+}$ from the substrate during the reaction process. Only Han et al. successfully developed a pure $\mathrm{Mg}-\mathrm{Al} \mathrm{LDH}$ film on $\mathrm{Mg}$ alloys using a complicated and time-consuming method. ${ }^{24,25}$ According to their study, carbonic acid was prepared by bubbling $\mathrm{CO}_{2}$ (solution $\mathrm{A}$ ) and an $\mathrm{Al}$ source was

Received: June 17, 2021

Accepted: August 17, 2021

Published: September 16, 2021 
(a)

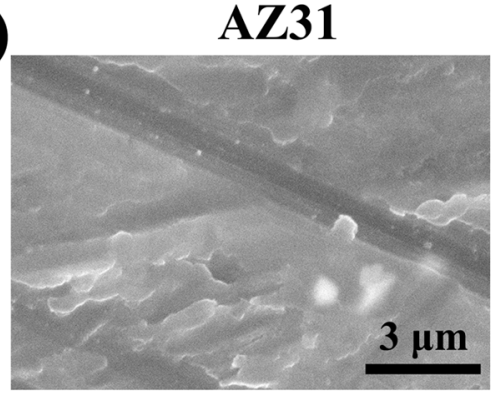

LDH\#

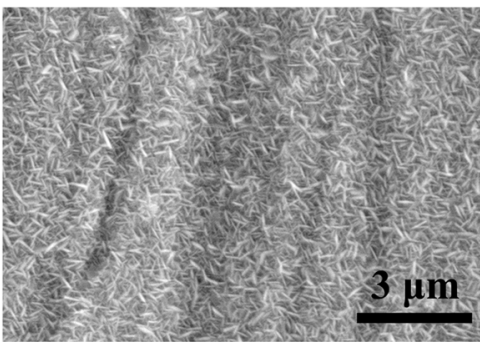

(b)

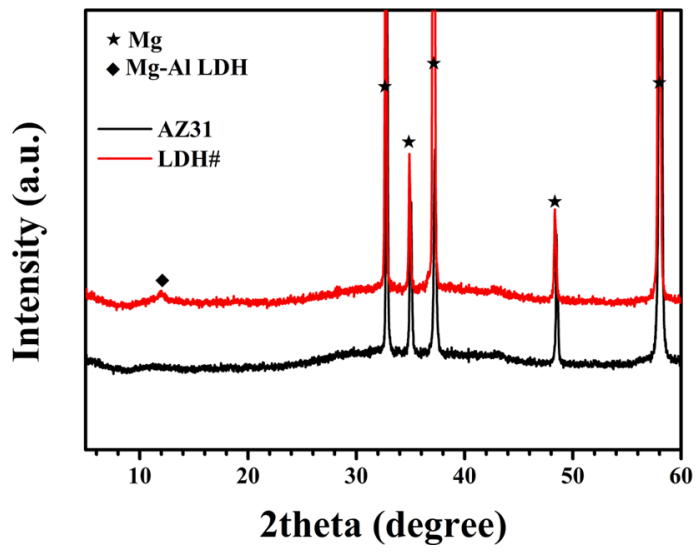

Figure 1. Surface morphologies (a) and XRD patterns (b) of AZ31 and LDH\# samples.

(a)

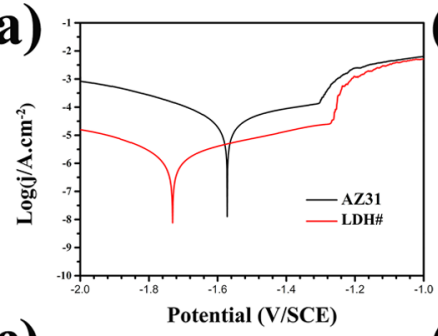

(c)

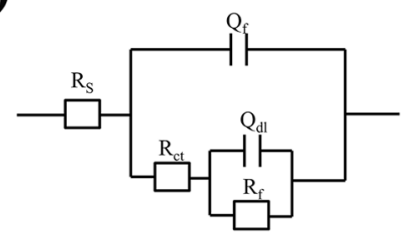

(b)

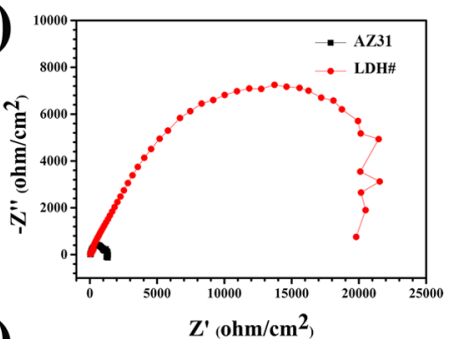

(d)

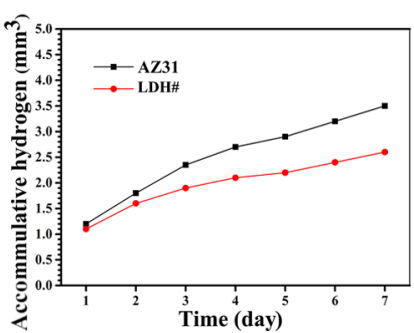

(e)
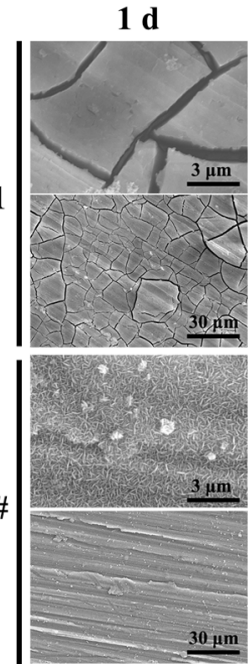
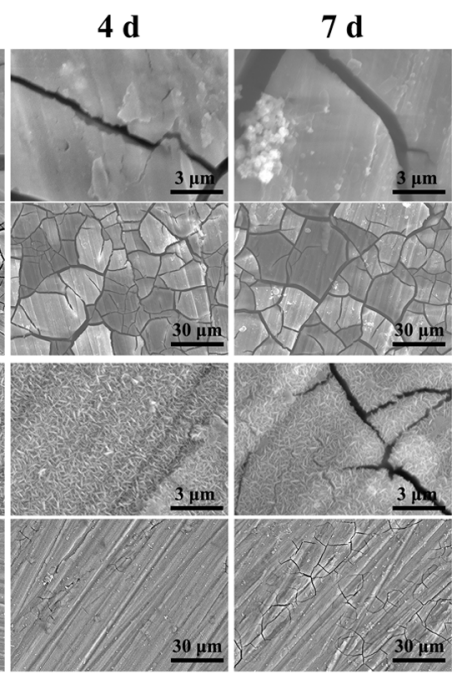

Figure 2. Potentiodynamic polarization (a) and EIS (b) results of AZ31 and LDH\#; equivalent circuit of EIS results (c); $R_{\mathrm{s}}$ is the solution resistance; $Q_{\mathrm{f}}$ and $R_{\mathrm{f}}$ are the capacitance and resistance of the corrosion production or coating on AZ31, respectively; $R_{\mathrm{ct}}$ and $Q_{\mathrm{dl}}$ are the chargetransfer resistance and the constant phase element of the electrical double layer, respectively; and accumulative hydrogen evolution (d) and surface views (e) of AZ31 and LDH\# samples after being immersed in PBS.

prepared by dissolving a pure $\mathrm{Al}$ plate in a $\mathrm{Na}_{2} \mathrm{CO}_{3}$ solution (solution B). Solution B was then added into solution A, and the $\mathrm{pH}$ value of the mixed solution was adjusted to 10.5 using $\mathrm{NaOH}$. Finally, the reaction solution was obtained. To broaden the application of $\mathrm{Mg}-\mathrm{Al} \mathrm{LDH}$ on the $\mathrm{Mg}$ substrate, it is highly important to design a new facile and time-saving method to fabricate a pure $\mathrm{Mg}-\mathrm{Al} \mathrm{LDH}$ film on $\mathrm{Mg}$ alloys.

In this study, a pure $\mathrm{Mg}-\mathrm{Al} \mathrm{LDH}$ film was formed on the surface of the AZ31 alloy via a two-step method. The $\mathrm{MgF}_{2}$ conversion film was first formed on the AZ31 alloy using hydrofluoric acid treatment, and the as-obtained $\mathrm{MgF}_{2}$ was then transferred to $\mathrm{Mg}-\mathrm{Al} \mathrm{LDH}$ (the final sample was denoted as $\mathrm{LDH \# )} \mathrm{using} \mathrm{hydrothermal} \mathrm{treatment.} \mathrm{In} \mathrm{vitro} \mathrm{and} \mathrm{in} \mathrm{vivo}$ corrosion resistance, histocompatibility, and osteogenesis ability of the as-prepared pure $\mathrm{Mg}-\mathrm{Al} \mathrm{LDH}$ film were investigated.

\section{RESULTS AND DISCUSSION}

2.1. Coating Characterizations. The surface views of the AZ31 alloy and LDH\# samples are shown in Figure 1a. Some scratches were observed on the surface of the AZ31 alloy, which were ascribed to the process of grounding using $\mathrm{SiC}$ 
paper. The surface of the LDH\# sample was uniformly deposited with micro-nano flakes, which are the typical morphologies of the $\mathrm{Mg}-\mathrm{Al} \mathrm{LDH} \mathrm{film.}{ }^{15}$ The X-ray diffraction (XRD) patterns are exhibited in Figure $1 \mathrm{~b}$. Only $\mathrm{Mg}$ feather peaks at approximately $12,18,38$, and $58^{\circ}$ were detected for the AZ31 sample. For the LDH\# sample, in addition to the characteristic peaks of $\mathrm{Mg}$, a peak at $12^{\circ}$ indicated the existence of $\mathrm{Mg}-\mathrm{Al} \mathrm{LDH}$ (JCPDS no. 50-1684). No feather peak at $18^{\circ}$ was detected, revealing that the formed $\mathrm{Mg}-\mathrm{Al}$ $\mathrm{LDH}$ was a pure phase without $\mathrm{Mg}(\mathrm{OH})_{2}$ impurity.

There have been many literature studies dedicated to fabricate $\mathrm{LDH}$ films on $\mathrm{Mg}$ alloys. ${ }^{7}$ However, owing to the fast release of $\mathrm{Mg}^{2+}$ from the substrate, the $\mathrm{LDH}$ film formed was accompanied by $\mathrm{Mg}(\mathrm{OH})_{2}$ impurity. Although the surface of the $\mathrm{Mg}$ alloy was pretreated to control the release of $\mathrm{Mg}^{2+}$ (such as anodic oxidation), the presence of $\mathrm{Mg}(\mathrm{OH})_{2}$ impurity was inevitable. ${ }^{20}$ Therefore, a new pretreatment was required to control the release of $\mathrm{Mg}^{2+}$. In this study, we used hydrofluoric acid treatment as pretreatment for three reasons: (1) hydrofluoric acid treatment is a commonly used method for the pretreatment of $\mathrm{Mg}$ alloys ${ }^{26}$ because the presence of the $\mathrm{MgF}_{2}$ passive film can improve its corrosion resistance; (2) few $\mathrm{F}$ elements are good for the biological performance of $\mathrm{Mg}$ based implants because proper $\mathrm{F}$ ions exhibit favorable antibacterial properties and induce bone formation properties; ${ }^{27}$ and (3) more importantly, the solubility product $\left(K_{\mathrm{sp}}\right)$ of $\mathrm{MgF}_{2}$ is higher than that of $\mathrm{Mg}(\mathrm{OH})_{2}\left(5.16 \times 10^{-11}\right.$ vs 5.61 $\times 10^{-12}$ at $25^{\circ} \mathrm{C}$ ) according to the Handbook of Inorganic Chemicals. A higher $K_{\mathrm{sp}}$ value of $\mathrm{MgF}_{2}$ indicates that $\mathrm{MgF}_{2}$ would gradually convert to $\mathrm{Mg}(\mathrm{OH})_{2}$ (reaction 1), which is the predecessor of $\mathrm{Mg}-\mathrm{Al} \mathrm{LDH}$. Therefore, the formation of a pure $\mathrm{Mg}-\mathrm{Al} \mathrm{LDH}$ film is possible by controlling the formation of $\mathrm{Mg}(\mathrm{OH})_{2}$.

$$
\mathrm{MgF}_{2}+2 \mathrm{OH}^{-} \rightarrow \mathrm{Mg}(\mathrm{OH})_{2}+2 \mathrm{~F}^{-}
$$

In this study, the $\mathrm{MgF}_{2}$ film gradually dissolved and released proper $\mathrm{Mg}^{2+}$ to form $\mathrm{Mg}-\mathrm{Al} \mathrm{LDH}$, and finally, a pure $\mathrm{Mg}-\mathrm{Al}$ LDH film was obtained.

2.2. Corrosion Resistance and Biocompatibility of the Pure Mg-Al LDH Film. The potentiodynamic polarization curves are shown in Figure 2a, and the calculated values of corrosion potential $\left(E_{\text {corr }}\right)$, corrosion current density $\left(j_{\text {corr }}\right)$, and corrosion resistance $\left(R_{\mathrm{p}}\right)$ are illustrated in Table 1 . The $E_{\text {corr }}$

Table 1. Corrosion Data of AZ31 and LDH\# Samples

\begin{tabular}{lcccc} 
& $E_{\text {corr }}(\mathrm{V})$ & $j_{\text {corr }}\left(\mathrm{A} / \mathrm{cm}^{2}\right)$ & $R_{\mathrm{p}}\left(\Omega / \mathrm{cm}^{2}\right)$ & $R_{\mathrm{ct}}\left(\Omega / \mathrm{cm}^{2}\right)$ \\
AZ31 & -1.58 & $2.24 \times 10^{-5}$ & $5.40 \times 10^{4}$ & 74.61 \\
LDH\# & -1.73 & $9.72 \times 10^{-7}$ & $1.39 \times 10^{6}$ & 561.60 \\
\hline
\end{tabular}

value of the LDH\# sample was lower than that of the AZ31 sample, which was also observed by other researchers. ${ }^{28}$ The $j_{\text {corr }}$ value of LDH\# $\left(9.72 \times 10^{-7} \mathrm{~A} / \mathrm{cm}^{2}\right)$ was 2 orders lower than that of AZ31 $\left(2.4 \times 10^{-5} \mathrm{~A} / \mathrm{cm}^{2}\right)$, and the $R_{\mathrm{p}}$ value was 2 orders higher than that of $\mathrm{AZ31}$, suggesting that the $\mathrm{Mg}-\mathrm{Al}$ LDH film can effectively protect the substrate. Numerous studies have prepared the $\mathrm{Mg}-\mathrm{Al} \mathrm{LDH}$ film on $\mathrm{Mg}$ alloys; however, because of the existence of the $\mathrm{Mg}(\mathrm{OH})_{2}$ phase, their $j_{\text {corr }}$ values are higher than the $j_{\text {corr }}$ value in this study. For example, Anjum et al. fabricated a coating with $\mathrm{Mg}-\mathrm{Al} \mathrm{LDH}$ and $\mathrm{Mg}(\mathrm{OH})_{2}$ mixed phases on $\mathrm{AZ31}$, and the sample exhibited a $j_{\text {corr }}$ value of $6.74 \times 10^{-6} \mathrm{~A} / \mathrm{cm}^{2} ;{ }^{29}$ Kuang et al. reported a $\mathrm{Mg}-\mathrm{Al} \mathrm{LDH}$ and $\mathrm{Mg}(\mathrm{OH})_{2}$ mixed phase coating on pure $\mathrm{Mg}$ using a two-step method, and the modified sample exhibited a $j_{\text {corr }}$ value of $4 \times 10^{-5} \mathrm{~A} / \mathrm{cm}^{2}{ }^{30}$

Electrochemical impedance spectroscopy (EIS) was also applied to analyze the corrosion behavior of the samples, and the result is presented in Figure $2 \mathrm{~b}$. The LDH\# sample showed significantly larger impedance than AZ31 did. The fitted electrical circuit can be illustrated as $R_{\mathrm{s}}\left[Q_{\mathrm{f}}\left(R_{\mathrm{f}}\left(Q_{\mathrm{dl}} R_{\mathrm{ct}}\right)\right)\right]$ (Figure $2 \mathrm{c}$ ), where $R_{\mathrm{ct}}$ represents the reaction resistance, and the calculated values of $R_{\mathrm{ct}}$ are shown in Table 1 . The $R_{\mathrm{ct}}$ value of the LDH\# sample was approximately 7.6 times that of the AZ31 sample. These electrochemical results revealed that the LDH\# sample possessed a better corrosion resistance than the AZ31 sample. To further evaluate the performance of the asprepared LDH film, the samples were immersed in phosphatebuffered saline (PBS) for 7 days. The amount of hydrogen released and surface views are shown in Figure 2d,e, respectively. Hydrogen released from the LDH\# sample was less that from the AZ31 sample, indicating that the substrate of the LDH-coated sample suffered from less corrosion. Furthermore, the accumulative release of $\mathrm{Mg}$ ions (Figure S1) from the samples was consistent with the result of hydrogen evolution. Many cracks were observed on the surface of AZ31 at day 1, indicating severe corrosion (Figure 2e). However, no cracks were observed on the surface of the LDH\# sample until day 4. Some cracks appeared on the LDH\# sample after being immersed for 7 days, but the number of the cracks is less and the width is narrower than that on the AZ31 sample. This suggested that the $\mathrm{Mg}-\mathrm{Al} \mathrm{LDH}$ film can effectively resist the attack of the corrosive medium.

Good cytocompatibility is a crucial parameter for implant biomaterials. Figure $3 \mathrm{a}$ demonstrates the early adhesion morphology of MC3T3-E1. No cells were observed on the surface of AZ31 at three detected time points. However, the spreading cells were observed on the LDH\# surface after culturing for $1 \mathrm{~h}$. The spreading area of the cells increased along with time, and a numerous amount of filopodia and lamellipodia were detected at $24 \mathrm{~h}$. Figure $3 \mathrm{~b}$ shows the fluorescence images of MC3T3-E1 after being cultured for 3 days. A few dead cells and no living cells were detected on the surface of AZ31. However, living cells were covered on the surface of the LDH\# sample. Even by culturing for 7 and 14 days, a large number of living cells covered the surface of the LDH\# sample (Figure S2). The cytocompatibility of the sample extracts was also evaluated, and the result is demonstrated in Figure 3c. The cells cultured in the extract of AZ31 exhibited cell viability below $70 \%$ at days 3 and 5, indicating severe cytotoxicity. However, when cultured in the extract of $\mathrm{LDH} \#$, the cell viability was nearly $100 \%$. A pure $\mathrm{Mg}-\mathrm{Al} \mathrm{LDH}$ film on AZ31 is suitable for cells to adhere and proliferate on its surface, and no cytotoxicity was found in its extract, suggesting a good biocompatibility.

In our previous study, a film composed of $\mathrm{Mg}-\mathrm{Al} \mathrm{LDH}$ and $\mathrm{Mg}(\mathrm{OH})_{2}$ was found to significantly enhance the corrosion resistance of the JDBM alloy. ${ }^{15}$ This was because the $\mathrm{Mg}-\mathrm{Al}$ $\mathrm{LDH}$ could resist the attack of chloride ions via anion exchangeability. ${ }^{31,32}$ However, the cells showed poor adhesion and proliferation in such a film, indicating that a more protective film was needed. Hence, we focused on fabricating a pure $\mathrm{Mg}-\mathrm{Al} \mathrm{LDH}$ film on the $\mathrm{Mg}$ alloy. In this work, the asprepared pure $\mathrm{Mg}-\mathrm{Al} \mathrm{LDH}$-coated AZ31 showed significantly higher corrosion resistance compared to bare AZ31. For bare AZ31, poor corrosion resistance means that a large amount of $\mathrm{Mg}$ ions is released from the substrate, resulting in the increase 
(a)

AZ31
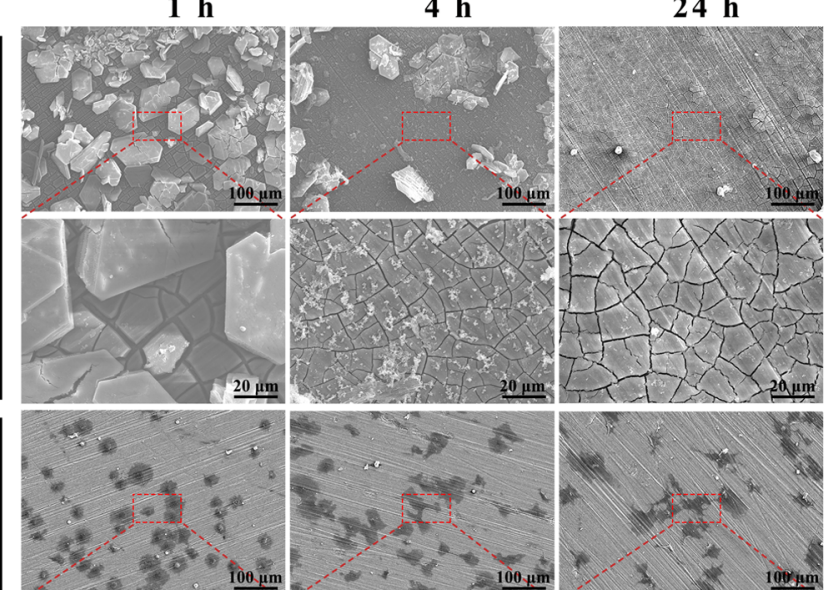

LDH\#
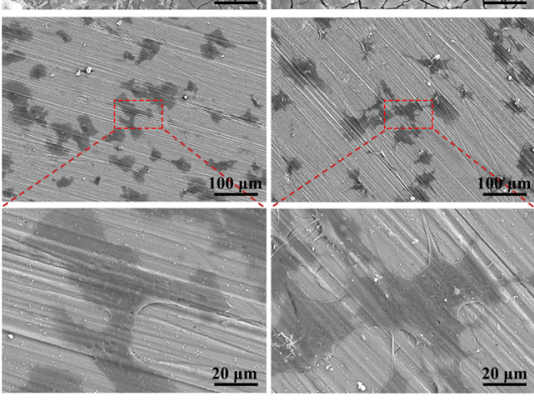

(b)

AZ31

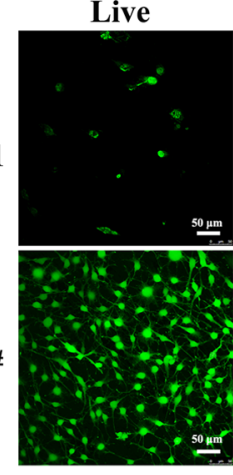

Merge

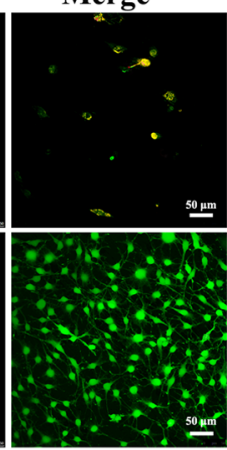

(c)

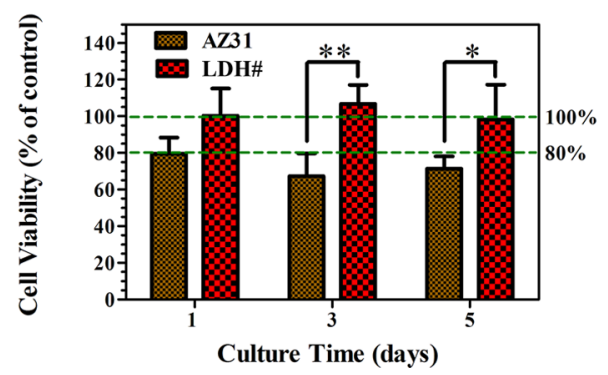

Figure 3. SEM images of MC3T3-E1 after being cultured on AZ31 and LDH\# samples for 1, 4, and $24 \mathrm{~h}$ (a); live/dead staining images of MC3T3E1 after being cultured on AZ31 and LDH\# for 3 days (b), green represents living cells and red represents dead cells; and cell viability of MC3T3E1 after being cultured in the extracts of AZ31 and LDH\# for various durations (c).

of osmotic pressure. Meanwhile, a large amount of hydroxyl ions released from the substrate cause a sharp increase in the $\mathrm{pH}$ value. In the synergistic effects of the high osmotic pressure and $\mathrm{pH}$ value, cells cannot keep alive on the AZ31 surface. For LDH-coated AZ31, a favorable corrosion resistance means a milder osmotic pressure and $\mathrm{pH}$ value, so cells can keep alive and proliferate on its surface. Moreover, the nanostructure is reported to be favorable for cell adhesion and spreading. ${ }^{33}$ The $\mathrm{LDH \#}$ was covered by micro-nano flake structures, which is also beneficial for the cell adhesion.

2.3. In Vitro Osteogenic Differentiation and Angiogenesis Ability Evaluations. Alkaline phosphatase (ALP) activity and COL secretion are vital markers for the osteogenic differentiation of stem cells. For both the markers, larger and strongly stained areas were observed for the LDH\# group (Figure 4a). In addition, the osteogenic differentiation was evaluated at a molecular level. Figure $4 \mathrm{~b}$ displays the expression level of osteogenesis-related genes of MC3T3-E1. For all the detected genes, the cells cultured in the LDH\# extract exhibited a significantly higher expression than those in the AZ31 extract. Especially for the OCN expression, the LDH\# group was almost 6 times as much as that of the AZ31 group. Results of ALP activity, COL secretion, and bonerelated gene expression suggested that the pure $\mathrm{Mg}-\mathrm{Al} \mathrm{LDH}$ coated sample was more favorable for the osteogenic differentiation of MC3T3-E1.

In the past few years, extensive literature studies have revealed that angiogenesis is also important for new bone regeneration because a matured vasculature can sufficiently supply the required materials (such as nutrients, circulating cells, and oxygen) for bone growth. ${ }^{34-36}$ In this study, the angiogenic behavior of human umbilical vein endothelial cells (HUVECs) was evaluated by culturing in the extracts of AZ31 and LDH\# samples. The cell viability of HUVECs is presented in Figure 5a. After being cultured for 1 day, the cells showed a significantly higher viability in the LDH\# extract. After being (a)
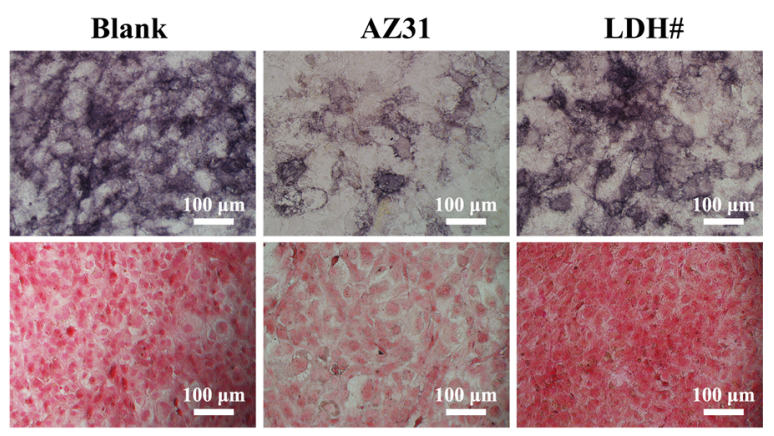

(b)

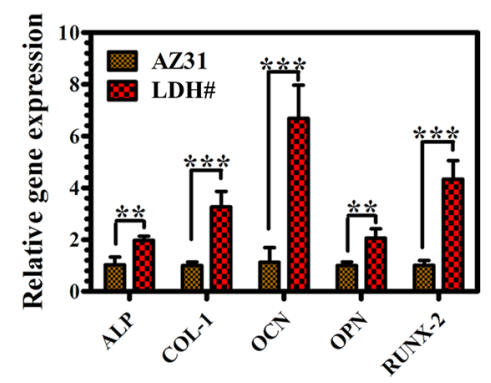

Figure 4. ALP-positive areas and COL secretion of MC3T3-E1 cultured in various extracts (a) and expression of osteogenesis-related genes in MC3T3-E1 cultured in various extracts (b).

cultured for 4 and 7 days, the viability of the cells in the LDH\# extract was still higher than that in the AZ31 extract, but no statistical differences were detected. The migration of HUVECs is a vital step for the formation of blood vessels. In this study, the migration of HUVECs was evaluated using a scratch assay (Figure 5b). A cross line with a width of $540 \pm$ $10 \mu \mathrm{m}$ was drawn by pipet tips. After culturing for $12 \mathrm{~h}$, the cells cultured in AZ31 and LDH\# extracts evidently migrated into the drawn area and left gaps of $343 \pm 8$ and $182 \pm 5 \mu \mathrm{m}$, respectively, indicating a better HUVEC migration for the 
(a)

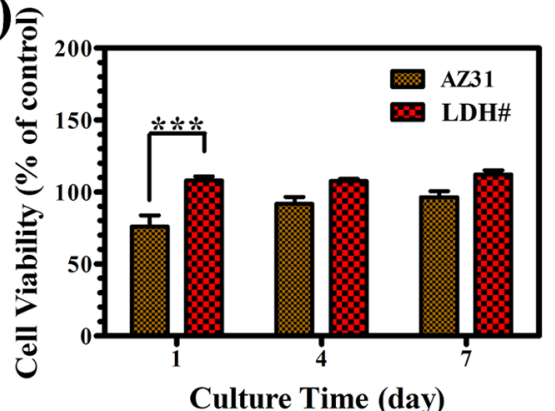

(c)

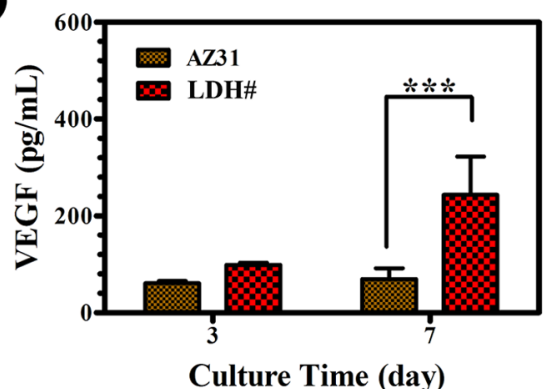

(b) AZ31 LDH\#

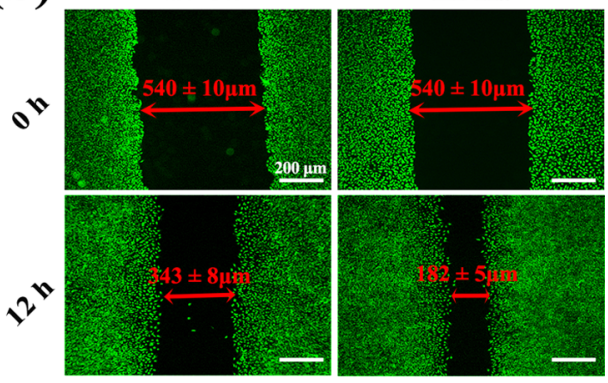

(d)

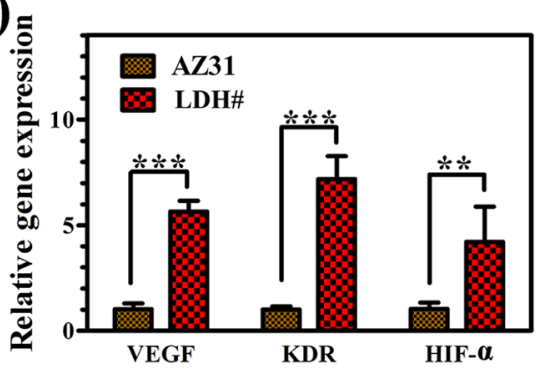

Figure 5. Cell viability (a), migration (b), VEGF protein levels (c), and angiogenesis-related gene expression (d) of HUVECs cultured in various extracts.

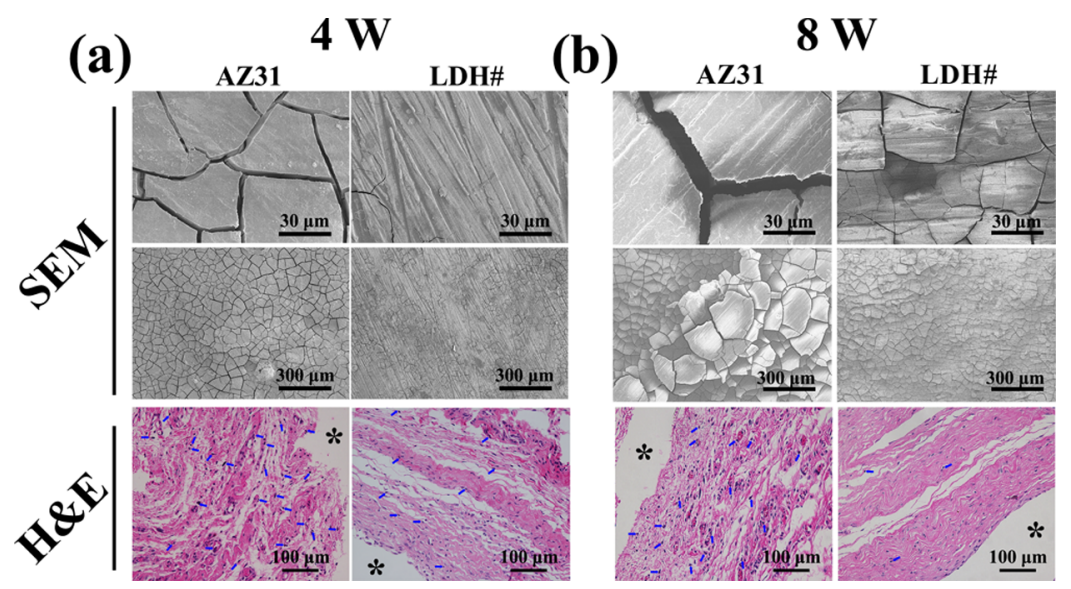

Figure 6. SEM views of the corroded surface and photomicrographs of the histological section of AZ31 and LDH\# samples after subcutaneous implantation for 4 (a) and 8 weeks (b).

LDH\# group. The vascular endothelial growth factor (VEGF) is a vital factor which plays an important role in the migration, proliferation, and vessel formation process of HUVECs. The secretion of VEGF protein was detected by enzyme-linked immunosorbent assay (ELISA), and the result is displayed in Figure 5c. At day 3, HUVECs cultured in the LDH\# extract secreted more VEGF proteins than those cultured in the AZ31 extract, but no statistical difference was detected. At day 7, the secreted VEGF level for the LDH\# group was significantly higher than that for the AZ31 group. Additionally, the expression level of angiogenesis-related genes was also detected (Figure 5d). The expressions of VEGF, KDR, and HIF- $\alpha$ gene for HUVECs cultured in the LDH\# extract were 4.6, 6.2, and 3.2 times higher than those cultured in AZ31 extracts, respectively. The results of ELISA and the real-time polymerase chain reaction (RT-PCR) verified the enhanced angiogenic behaviors of the pure $\mathrm{Mg}-\mathrm{Al} \mathrm{LDH}$-coated sample at a molecule and gene level.
As revealed by the electrochemical and immersion tests (Figure 2), $\mathrm{Mg}-\mathrm{Al} \mathrm{LDH}$-modified AZ31 exhibited a significantly better corrosion resistance. Therefore, the LDH\# sample showed less $\mathrm{Mg}$ ion release and a milder increase of the $\mathrm{pH}$ value. A suitable amount of $\mathrm{Mg}$ ions and $\mathrm{pH}$ value are favorable for the cell adhesion, spreading, and proliferation (Figure 3) and thus guarantee the favorable osteogenesis- and angiogenesis-inducing capabilities of the LDH\# sample.

2.4. In Vivo Evaluations. Subcutaneous implantation was applied to evaluate the in vivo corrosion resistance and histocompatibility of AZ31 and LDH\# samples, and the results are presented in Figure 6. After being implanted for 4 weeks (Figure 6a), cracks were evenly distributed on the surface of AZ31, while only few cracks were observed on the surface of the LDH\# sample. Notably, the LDH structures were retained on the surface of LDH\# (Figure S3a). After being implanted for 8 weeks (Figure $6 \mathrm{~b}$ ), the width of cracks on AZ31 appeared to be larger than that at week $4(8.6 \pm 0.7 v s 4 \pm 0.5 \mu \mathrm{m})$. A 
(a)

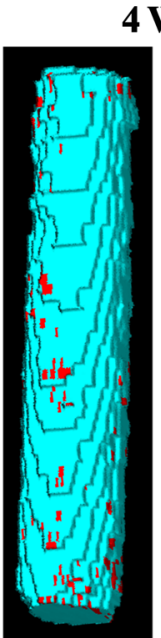

AZ31
$4 \mathrm{~W}$

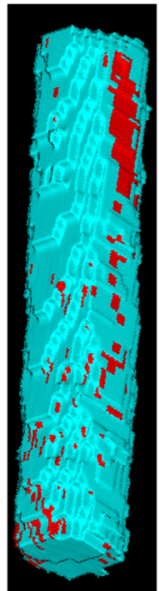

LDH\#

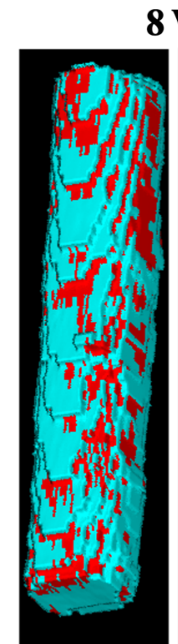

AZ31
$8 \mathrm{~W}$

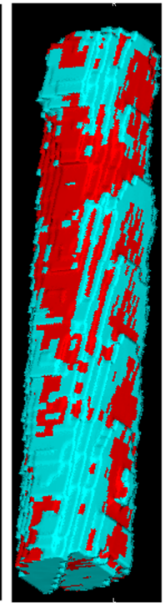

LDH\#

(c)

AZ31

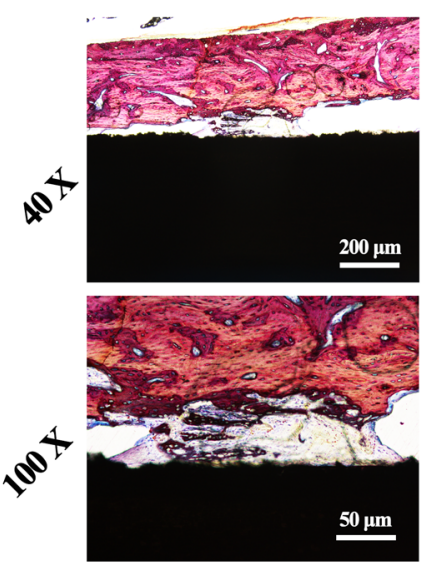

LDH\#
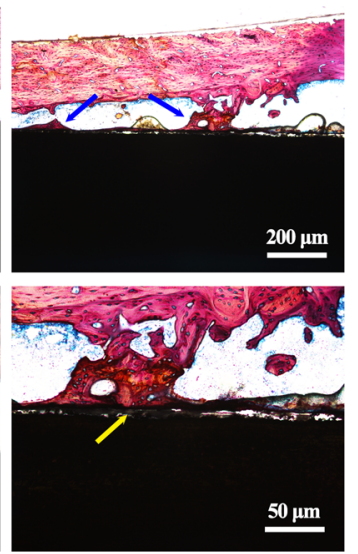

4 weeks

(b)
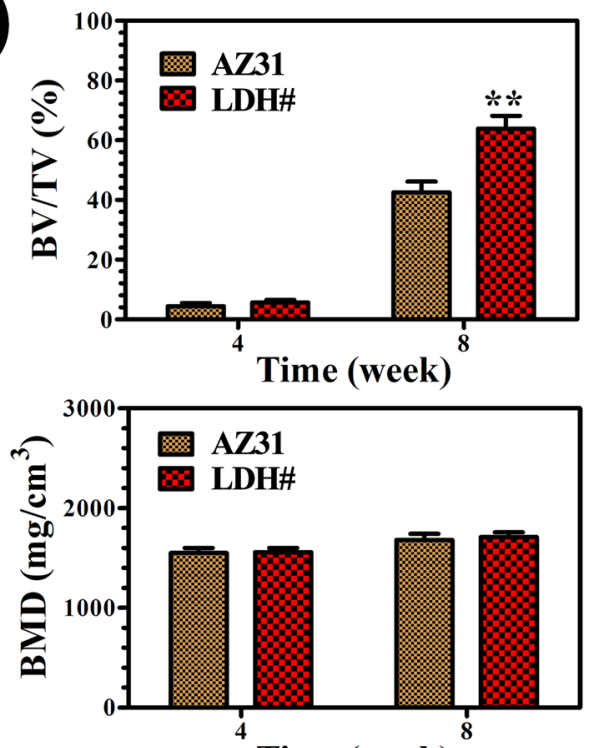

Time (week) (d)

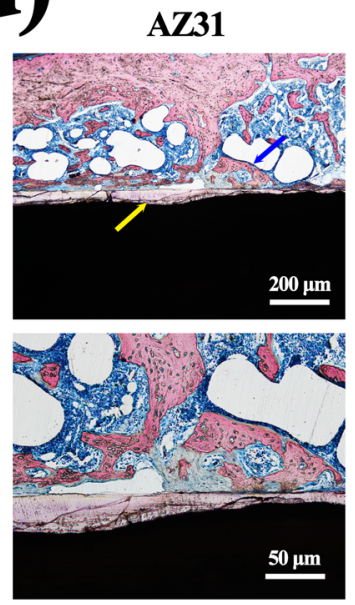

LDH\#

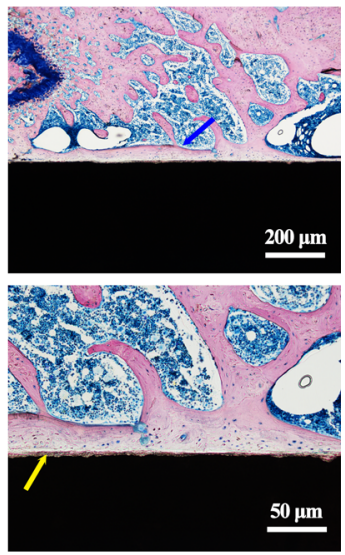

8 weeks

Figure 7. $3 \mathrm{D}$ reconstruction images of micro-CT results (a), red sections indicate new bones; calculated $\mathrm{B} V / \mathrm{TV}$ and trabecular BMD (b); and VG staining of AZ31 and LDH\# samples after femur implantation for 4 weeks (c) and 8 weeks (d), blue arrow indicates the newly formed bone and yellow arrow indicates the corrosion product.

more number of cracks were observed on the LDH\# surface, but the width of cracks was narrower than that on AZ31 at week 4 ( $1.4 \pm 0.2 v s 4 \pm 0.5 \mu \mathrm{m})$, suggesting improved in vivo corrosion resistance by the $\mathrm{Mg}-\mathrm{Al} \mathrm{LDH}$ film. In addition, $\mathrm{LDH}$ structures were also maintained on the surface (Figure S3b), revealing a good stability of LDH structures in vivo. At week 4 , the hematoxylin and eosin (H\&E) staining result suggested that both the samples would induce a local inflammation response (verified by neutrophils), but the LDH\# group was milder than the AZ31 group. At week 8, numerous neutrophils were detected on the tissue of the AZ31 group, while only a few neutrophils were observed on the tissue of the LDH\# group. These results revealed that the inflammation reaction caused by AZ31 cannot be eliminated by host healing ability, but the inflammation reaction caused by the LDH\# sample can be healed after 8 weeks, indicating a favorable in vivo histocompatibility.

Femur implantation was carried out to evaluate the osteointegration capability of AZ31 and LDH\# samples. Figure 7a illustrates the reconstructed three-dimensional (3D) micro$\mathrm{CT}$ images. The calculated bone volume/tissue volume (BV/ $\mathrm{TV}$ ) and bone mineral density (BMD) values are presented in Figure $7 \mathrm{~b}$. The new bone volume was visually larger for the LDH\# group than for the AZ31 group at both weeks 4 and 8 . However, the quantitative analysis of the BT/TV value showed that there was no significant difference observed between AZ31 and LDH\# groups at week 4. Nevertheless, the BT/TV value of the LDH\# group was higher than that of the AZ31 group at week 8. As for the value of BMD, no significant difference was detected at both weeks 4 and 8. Many studies have proved that bare $\mathrm{Mg}$ implants show a higher $\mathrm{BMD}$ value than Ti implants. ${ }^{37,38}$ In this study, $\mathrm{Mg}$ ions would release from both AZ31 and LDH\# implants, so the BMD values of the two groups were in the same level. Furthermore, according to our previous study, the concentration of $\mathrm{Mg}$ ions in the range of 3.125-25 mM can improve cell viability, while once the concentration exceeds $25 \mathrm{mM}$, it would suppress cell viability. ${ }^{39}$ A large amount of $\mathrm{Mg}$ ions released from the AZ31 


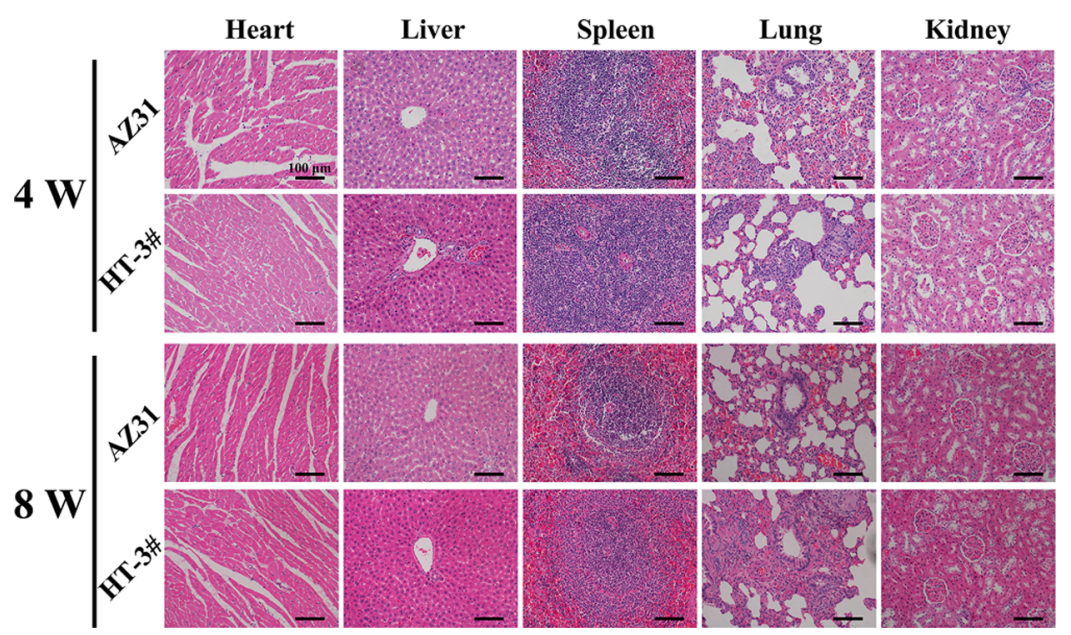

Figure 8. Typical histological morphology of important organic tissues in the H\&E sections of AZ31 and LDH\# samples after femur implantation for 4 and 8 weeks.

implant would do harm to cell viability, and thus, the AZ31 implant showed a lower BV/TV value than the LDH\# implant in this study.

Figure $7 \mathrm{c}, \mathrm{d}$ represents the histological sections of AZ31 and LDH\# groups stained with Van Gieson's (VG) solution. At week 4, few newly formed bones were observed surrounding the AZ31 implant. However, newly formed bones can be detected surrounding the LDH\# implant, but the bone (indicated by blue arrows) was discontinuous and corrosion products (indicated by yellow arrows) were observed in the gap between the new bone and the implant. Notably, the surface of AZ31 displayed a more serious corrosion morphology with many cracks (Figure S4), representing a poorer corrosion resistance in femur than that in the LDH\# implant. At week 8, a new bone grew into the marrow cavity for the AZ31 group. However, no new bone was detected near the surface of the implant, but a layer of corrosion products was detected. In the case of the LDH\# group, a great degree of continuous newly formed bone was directly bonded with the surface, indicating a superior osteointegration. These results suggested that the pure $\mathrm{Mg}-\mathrm{Al} \mathrm{LDH}$ film on AZ31 improved its osteogenesis and osteointegration ability. The H\&E staining of different organs after femur implantation for 4 and 8 weeks is represented in Figure 8. For both AZ31 and LDH\# groups, no pathological changes were observed in the heart, liver, spleen, lung, and kidney, indicating favorable biosafety of both the implants.

For biodegradable metals, the in vivo performances are mainly decided by their corrosion behaviors. Hence, for the LDH\# implant, because it showed enhanced corrosion resistance, a milder inflammation reaction in subcutaneous and a better osteointegration in femur were prospective.

\section{CONCLUSIONS}

In this work, pure $\mathrm{Mg}-\mathrm{Al} \mathrm{LDH}$-coated $\mathrm{AZ31}$ was fabricated by combining hydrofluoric acid pretreatment and hydrothermal treatment. The $\mathrm{Mg}-\mathrm{Al} \mathrm{LDH}$-coated sample exhibited better in vitro corrosion resistance and was more suitable for the osteogenic differentiation of MC3T3-E1 and vascularization of HUVECs. Subcutaneous implantation suggested that $\mathrm{Mg}-\mathrm{Al}$ LDH could protect the AZ31 substrate from severe corrosion and induce a mild host inflammation response. Femur implantation suggested that $\mathrm{Mg}-\mathrm{Al} \mathrm{LDH}$-coated AZ31 showed enhanced osseointegration. In summary, with enhanced corrosion resistance, biocompatibility, and osteointegration, the novel and simple in situ method to fabricate pure $\mathrm{Mg}-\mathrm{Al} \mathrm{LDH}$ films on $\mathrm{Mg}$ alloys shows a promising potential for orthopedic applications.

\section{MATERIALS AND METHODS}

4.1. Sample Preparation and Characterization. Commercially purchased AZ31 alloys (ChuanMao Metal material Co., Ltd., Suzhou) were used as substrates. The AZ31 alloys were immersed in a hydrofluoric acid solution (40 v/v\%; Sinopharm Chemical Reagent Co., Ltd., Shanghai) for 6 h. Subsequently, the hydrofluoric acid-treated AZ31 alloys were placed in a Teflon-lined stainless-steel container. The reaction solution was $0.02 \mathrm{M} \mathrm{Al}\left(\mathrm{NO}_{3}\right)_{3}(\mathrm{pH}=12.8$ adjusted by $\mathrm{NaOH}$ ), and the stainless-steel container was kept at 120 ${ }^{\circ} \mathrm{C}$ for $12 \mathrm{~h}$. The obtained samples were denoted as LDH\#.

The surface morphology was observed using scanning electron microscopy (SEM; Hitachi-S3400N, Hitachi, Japan). The phase compositions were detected using XRD (D/Max, RIGAKU, Tokyo, Japan) with $\mathrm{Cu} \mathrm{K} \alpha$ radiation (40 kV, 30 $\mathrm{mA})$.

4.2. Corrosion Evaluation. The corrosion resistance of the samples was evaluated by an electrochemical analyzer (CHI760C; Shanghai, China) in PBS. Potentiodynamic polarization and impedance spectra tests were both carried out in a three-electrode electrochemical cell. The exposure area of the sample to the electrolyte was $0.255 \mathrm{~cm}^{2}$. The samples were stabilized in PBS to obtain a stable open-circuit potential before the test. The potentiodynamic polarization test was performed at a scanning rate of $10 \mathrm{mV} / \mathrm{s}$. The values of $E_{\text {corr }}$, $j_{\text {corr }}$, and $R_{\mathrm{p}}$ were determined using the Tafel extrapolation. The impedance spectra test was performed by applying a $5 \mathrm{mV}$ sinusoidal perturbing signal and recorded from $100 \mathrm{kHz}$ to 10 $\mathrm{mHz}$. ZView software was used to analyze the result.

The AZ31 alloy and LDH\# samples were put in $400 \mathrm{~mL}$ beakers (four specimens of each group in one beaker), and 360 $\mathrm{mL}$ of PBS was then added. The hydrogen released was collected using inverted funnels and was recorded every day for 7 days. The corrosion morphologies of the samples after being immersed in PBS for 1, 4, and 7 days were observed by SEM.

4.3. In Vitro Cytocompatibility. 4.3.1. Cell Culture. Osteoblast-like cells (MC3T3-E1, Cells Resource Center of 
Shanghai Institute for Biological Science, Shanghai, China) and HUVECs (ScienceCell, USA) were used. MC3T3-E1 was cultured in the $\alpha$-minimum essential medium ( $\alpha$-MEM) containing $10 \%$ fetal bovine serum (FBS, Hyclone, USA) and $1 \%$ antimicrobial penicillin/streptomycin mixture $(\mathrm{P} / \mathrm{S}$, Hyclone, USA). HUVECs were cultured in the endothelial cell medium (ECM) containing $10 \% \mathrm{FBS}, 1 \% \mathrm{P} / \mathrm{S}$, and $2.5 \%$ VEGF (Hyclone, USA). Cells were incubated at $37^{\circ} \mathrm{C}$ in a $5 \%$ $\mathrm{CO}_{2}$ incubator. The samples were sterilized by ultraviolet radiation before use.

4.3.2. Cell Adhesion. The samples were placed in 24-well plates and added with $1 \mathrm{~mL}$ of cell suspension containing $5 \times$ $10^{4}$ cells. After 1,4 , and $24 \mathrm{~h}$ incubation, the culture media were removed, and the samples were rinsed three times with PBS. Subsequently, the wells were added with $2.5 \%(\mathrm{v} / \mathrm{v})$ glutaraldehyde and kept at $4{ }^{\circ} \mathrm{C}$ overnight. The cells were then dehydrated and then observed using SEM.

4.3.3. Live-Dead Staining. The cells were cultured on the AZ31 alloy and LDH\# samples for 3 days. Then, the cells were rinsed three times with PBS and then added with $100 \mu \mathrm{L}$ of dyeing solution ( $5 \mu \mathrm{M}$ propidium iodide and $2 \mu \mathrm{M}$ calciumAM, Sigma, USA). After being cultured for another $15 \mathrm{~min}$, the cells were rinsed with PBS and kept in PBS. The cells were observed using confocal laser scanning microscopy (Leica SP8, Germany).

4.3.4. Cell Viability in Extracts. The extracts of different samples were obtained by immersing the samples in the culture media ( $\alpha$-MEM and ECM) for $24 \mathrm{~h}$ with an area-volume ratio of $1.25 \mathrm{~cm}^{2} / \mathrm{mL}$. $\alpha$-MEM or ECM was used as positive control groups. $100 \mu \mathrm{L}$ of MC3T3-E1 or HUVEC suspension with $5 \times$ $10^{3}$ cells was added to 96-well plates. After being cultured for 1 day, the culture media were replaced with various extracts and incubated for another 1, 3, and 5 days. The Alamar Blue assay (AbD Serotec Ltd., UK) was applied to evaluate the cell viability according to the manufacturer's instruction.

4.4. In Vitro Osteogenic Differentiation of MC3T3-E1. 4.4.1. Alkaline Phosphatase Activity and Collagen Secretion. MC3T3-E1 was cultured on various extracts for 7 days. The cells were fixed with $4 \%$ paraformaldehyde, and then, ALP activity staining was applied with AS-MX phosphate, fast blue RR salt, and Mayer's hematoxylin solution. Images were captured using a phase-contrast inverted optics microscope.

For collagen (COL) detection, the cells were fixed with $4 \%$ para-formaldehyde and stained with $0.1 \%$ Sirius Red. The stained cells were pictured using an optics microscope.

4.4.2. Quantitative RT-PCR Analysis. The gene expressions, including ALP, type-1 COL , osteocalcin, osteopontin, and runt-related transcription factor 2, were measured on MC3T3E1 after being cultured for 7 days. Total RNA was isolated using a Trizol reagent (Invitrogen, CA, USA). After quantifying the concentration using nanodrop 2000 (ThermoFisher, USA), the acquired RNA was reverse transcribed into cDNA using the 1st Strand cDNA synthesis supermix Kit (Yeasen, China). Furthermore, the cDNA was analyzed by RTPCR using SYBR Green Mastermix (Yeasen, China) and primers. The running program of RT-PCR included an initial denaturation period of $1.5 \mathrm{~min}$ at $95{ }^{\circ} \mathrm{C}, 40$ cycles at $95{ }^{\circ} \mathrm{C}$ for $15 \mathrm{~s}$, and at $60{ }^{\circ} \mathrm{C}$ for $30 \mathrm{~s}$. GAPDH was selected as a housekeeping gene. The primer sequences are listed in Table S1.

4.5. In Vitro Angiogenic Behavior of HUVECs. 4.5.1. Cell Migration. HUVECs were seeded on the 24-well plate at a density of $1 \times 10^{5}$ cells/well. After being cultured for
1 day, lines were drawn across the cell layer using $200 \mu \mathrm{L}$ pipet tips and then added various extracts. After another $8 \mathrm{~h}$, the cells were fixed with $4 \%$ paraformaldehyde, permeabilized with $0.1 \%$ Triton X-100, stained with rhodamine-phalloidin and DAPI, and observed using a fluorescence microscope (Olympus IX 71, Olympus, Japan).

4.5.2. Quantification of VEGF Protein Secretion. HUVECs were seeded on the 24 -well plate at a density of $2 \times 10^{4}$ cells/ well. After $4 \mathrm{~h}$, the culture media were replaced with various extracts and incubated for 3 and 7 days. After that, the secretion of VEGF protein was quantified using the ELISA kit (Abcam, USA) according to the manufacturer's instruction.

4.5.3. Quantitative RT-PCR Analysis. The gene expressions of the kinase insert domain receptor, hypoxia-inducible factor 1-alpha (HIF- $\alpha$ ), and VEGF of HUVECs were measured according to Section 4.4.2. The primer sequences are listed in Table S1.

4.6. Animal Experiment. All the animal experiments were approved by the Animal Care and Use Committee of Guangdong General Hospital. Sprague-Dawley rats (5-week old; adult male) were used.

4.6.1. Subcutaneous Implantation. Eight rats were anesthetized by intraperitoneal injection of pentobarbital sodium $(40 \mathrm{mg} / \mathrm{Kg})$. The skin on the back was shaved and sterilized with $2 \%$ iodine. Two pockets were sliced on each rat on their bilateral back and then implanted with the samples. Four rats were sacrificed at 4 weeks, and the others were sacrificed at 8 weeks.

The surface morphologies of the implanted samples were viewed using SEM. The tissues surrounding the implants were collected and fixed with paraformaldehyde, dehydrated, embedded in paraffin, and stained with H\&E to evaluate the inflammatory reaction.

4.6.2. Femur Implantation. Eight rats were anesthetized by intraperitoneal injection of pentobarbital sodium $(40 \mathrm{mg} / \mathrm{Kg})$. The lateral sides of the knee joints were carefully exposed via skin incision and muscle blunt dissection. Holes ( $\Phi 2 \mathrm{~mm}$ ) were predrilled longitudinally into femur, and the materials were then implanted. The wound was closed in layers and injected with prophylactic antibiotics consecutively for 3 days. The bilateral femurs were harvested at 4 and 8 weeks after implantation. Furthermore, tissues, including heart, liver, spleen, lung, and kidney, were collected and fixed in $4 \%$ paraformaldehyde. The obtained tissues were dehydrated, embedded in paraffin, and stained with H\&E.

The harvested femurs containing implants were scanned using Micro-CT (Quantum FX, PerkinElmer), and more than 500 layers were imaged at the implanted site. Multimodal 3D Visualization (Siemens, Germany) software was used to reconstruct the $3 \mathrm{D}$ images. VG Studio MAX software was used to calculate the $\mathrm{B} V / \mathrm{T} V$ and the $\mathrm{BMD}$.

After micro-CT imaging, the femur specimens were dehydrated using gradient ethanol, embedded in polymethylmethacrylate, cut into longitudinal sections $(100 \mu \mathrm{m})$ using a saw microtome (EXAKT Apparatebau, Germany), and then ground and polished to a final thickness of approximately 50 $\mu \mathrm{m}$. The polished sections were stained with VG solution and visualized using an optics microscope.

4.7. Statistical Analysis. All data are presented as mean \pm standard deviation. Statistical analyses were performed using one-way ANOVA, followed by using Tukey's post hoc test via SPSS 19.0 software. Statistical significance was confirmed when the $P$-value was $<0.05$. 


\section{ASSOCIATED CONTENT}

\section{s) Supporting Information}

The Supporting Information is available free of charge at https://pubs.acs.org/doi/10.1021/acsomega.1c03169.

Primer sequence of tested genes in quantitative RTPCR; accumulative release of $\mathrm{Mg}$ ions from $\mathrm{AZ31}$ and LDH\# samples; live/dead staining images of MC3T3-E1 after being cultured on AZ31 and LDH\# for 7 and 14 days; surface morphology of the LDH\# implant after subcutaneous implantation for 4 and 8 weeks; and surface morphology of AZ31 and LDH\# implants after femur implantation for 4 weeks (PDF)

\section{AUTHOR INFORMATION}

\section{Corresponding Authors}

Hua Zhong - The Fifth Affiliated Hospital of Southern Medical University, Guangzhou 510920, China; Phone: 8613760776599; Email: zhong8099@163.com

Feng Peng - Department of Orthopedics, Research Center of Medical Sciences, Guangdong Provincial People's Hospital, Guangdong Academy of Medical Sciences, Guangzhou,

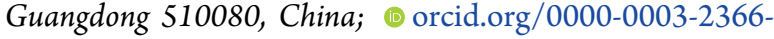
2253; Phone: 86-18616936841; Email: peng_feng7@ 163.com

Yu Zhang - Department of Orthopedics, Research Center of Medical Sciences, Guangdong Provincial People's Hospital, Guangdong Academy of Medical Sciences, Guangzhou, Guangdong 510080, China; The Second School of Clinical Medicine, Southern Medical University, Guangzhou 510515, China; Phone: 86-13602744495; Email: zhangyu@ gdph.org.cn

\section{Authors}

Shi Cheng - Department of Orthopedics, Research Center of Medical Sciences, Guangdong Provincial People's Hospital, Guangdong Academy of Medical Sciences, Guangzhou, Guangdong 510080, China

Lvqin Lan - Department of Orthopedics, Research Center of Medical Sciences, Guangdong Provincial People's Hospital, Guangdong Academy of Medical Sciences, Guangzhou, Guangdong 510080, China

Mei Li - Department of Orthopedics, Research Center of Medical Sciences, Guangdong Provincial People's Hospital, Guangdong Academy of Medical Sciences, Guangzhou, Guangdong 510080, China

Xiao Chu - Department of Orthopedics, Research Center of Medical Sciences, Guangdong Provincial People's Hospital, Guangdong Academy of Medical Sciences, Guangzhou, Guangdong 510080, China

Mengyu Yao - Department of Orthopedics, Research Center of Medical Sciences, Guangdong Provincial People's Hospital, Guangdong Academy of Medical Sciences, Guangzhou, Guangdong 510080, China

Complete contact information is available at: https://pubs.acs.org/10.1021/acsomega.1c03169

\section{Author Contributions}

S.C. and L.L. contributed equally to this work. S.C. and L.L.: conceptualization, investigation, methodology, and data curation. M.L., X.C., and M.Y.: supervision, project administration, and data curation. F.P., H.Z., and Y.Z.: supervision, funding acquisition, review, and editing.

\section{Notes}

The authors declare no competing financial interest.

\section{ACKNOWLEDGMENTS}

Financial support from the National Natural Science Foundation of China (52001076), Natural Science Foundation of Guangdong Province, China (2020A1515011447), Scientific and Technological Projects of Guangzhou, China (202002030283 and 202102020431), and Medical Science Foundation of Guangdong Province, China (A2020005) is gratefully acknowledged.

\section{REFERENCES}

(1) Buling, A.; Zerrer, J. Increasing the application fields of magnesium by ultraceramic: Corrosion and wear protection by plasma electrolytical oxidation (PEO) of $\mathrm{Mg}$ alloys. Surf. Coat. Technol. 2019, 369, 142-155.

(2) Yao, Y.; Chen, L.; Wang, W. Damping Capacities of (B4C+Ti) Hybrid Reinforced Mg and AZ91D Composites Processed by In Situ Reactive Infiltration Technique. Acta Metall. Sin. 2019, 55, 141-148.

(3) Wang, J.; Pang, X.; Pang, X.; Jahed, H. Surface protection of Mg alloys in automotive applications: A review. AIMS Mater. Sci. 2019, 6, $567-600$.

(4) Li, X.; Liu, X.; Wu, S.; Yeung, K. W. K.; Zheng, Y.; Chu, P. K. Design of magnesium alloys with controllable degradation for biomedical implants: From bulk to surface. Acta Biomater. 2016, 45, $2-30$.

(5) Chen, Y.; Xu, Z.; Smith, C.; Sankar, J. Recent advances on the development of magnesium alloys for biodegradable implants. Acta Biomater. 2014, 10, 4561-4573.

(6) Zhao, D.; Witte, F.; Lu, F.; Wang, J.; Li, J.; Qin, L. Current status on clinical applications of magnesium-based orthopaedic implants: A review from clinical translational perspective. Biomaterials 2017, 112, 287-302.

(7) Guo, L.; Wu, W.; Zhou, Y.; Zhang, F.; Zeng, R.; Zeng, J. Layered double hydroxide coatings on magnesium alloys: A review. J. Mater. Sci. Technol. 2018, 34, 1455.

(8) Yu, J.; Wang, Q.; O'Hare, D.; Sun, L. Preparation of two dimensional layered double hydroxide nanosheets and their applications. Chem. Soc. Rev. 2017, 46, 5950-5974.

(9) Zhao, M.-Q.; Zhang, Q.; Huang, J.-Q.; Wei, F. Hierarchical Nanocomposites Derived from Nanocarbons and Layered Double Hydroxides - Properties, Synthesis, and Applications. Adv. Funct. Mater. 2012, 22, 675-694.

(10) Syu, J.-H.; Uan, J.-Y.; Lin, M.-C.; Lin, Z.-Y. Optically transparent $\mathrm{Li}-\mathrm{Al}-\mathrm{CO} 3$ layered double hydroxide thin films on an AZ31 Mg alloy formed by electrochemical deposition and their corrosion resistance in a dilute chloride environment. Corros. Sci. 2013, 68, 238-248.

(11) Lin, J.-K.; Uan, J.-Y.; Wu, C.-P.; Huang, H.-H. Direct growth of oriented $\mathrm{Mg}$-Fe layered double hydroxide (LDH) on pure $\mathrm{Mg}$ substrates and in vitro corrosion and cell adhesion testing of LDHcoated Mg samples. J. Mater. Chem. 2011, 21, 5011.

(12) Wu, L.; Yang, D.; Zhang, G.; Zhang, Z.; Zhang, S.; Tang, A.; Pan, F. Fabrication and characterization of Mg-M layered double hydroxide films on anodized magnesium alloy AZ31. Appl. Surf. Sci. 2018, 431, 177-186.

(13) Ye, X.; Jiang, Z.; Li, L.; Xie, Z. H. In-Situ Growth of NiAlLayered Double Hydroxide on AZ31 Mg Alloy towards Enhanced Corrosion Protection. Nanomaterials 2018, 8, 411.

(14) Zhou, M.; Yan, L.; Ling, H.; Diao, Y.; Pang, X.; Wang, Y.; Gao, $\mathrm{K}$. Design and fabrication of enhanced corrosion resistance $\mathrm{Zn}-\mathrm{Al}$ layered double hydroxides films based anion-exchange mechanism on magnesium alloys. Appl. Surf. Sci. 2017, 404, 246-253.

(15) Peng, F.; Li, H.; Wang, D.; Tian, P.; Tian, Y.; Yuan, G.; Xu, D.; Liu, X. Enhanced Corrosion Resistance and Biocompatibility of Magnesium Alloy by Mg-Al-Layered Double Hydroxide. ACS Appl. Mater. Interfaces 2016, 8, 35033-35044. 
(16) Zhang, D.; Peng, F.; Tan, J.; Liu, X. Y. In-situ growth of layered double hydroxide films on biomedical magnesium alloy by transforming metal oxyhydroxide. Appl. Surf. Sci. 2019, 496, 143690.

(17) $\mathrm{Wu}, \mathrm{L}$. Influence of Reaction Temperature on the Controlled Growth of Mg-Al LDH Film. Int. J. Electrochem. Sci. 2017, 12, 63526364.

(18) Zhang, X.; Zhong, F.; Li, X.; Liu, B.; Zhang, C.; Buhe, B.; Zhang, T.; Meng, G.; Wang, F. The effect of hot extrusion on the microstructure and anti-corrosion performance of $\mathrm{LDHs}$ conversion coating on AZ91D magnesium alloy. J. Alloys Compd. 2019, 788, 756-767.

(19) Wu, L.; Pan, F.; Liu, Y.; Zhang, G.; Tang, A.; Atrens, A. Influence of $\mathrm{pH}$ on the growth behaviour of Mg-Al LDH films. Surf. Eng. 2018, 34, 674-681.

(20) Zhang, G.; Wu, L.; Tang, A.; Zhang, S.; Yuan, B.; Zheng, Z.; Pan, F. A Novel Approach to Fabricate Protective Layered Double Hydroxide Films on the Surface of Anodized Mg-Al Alloy. Adv. Mater. Interfaces 2017, 4, 1700163.

(21) Zhang, G.; Wu, L.; Tang, A.; Weng, B.; Atrens, A.; Ma, S.; Liu, L.; Pan, F. Sealing of anodized magnesium alloy AZ31 with MgAl layered double hydroxides layers. RSC $A d v$. 2018, 8, 2248-2259.

(22) Nakamura, K.; Shimada, Y.; Miyashita, T.; Serizawa, A.; Ishizaki, T. Effect of Vapor Pressure During the Steam Coating Treatment on Structure and Corrosion Resistance of the $\mathrm{Mg}(\mathrm{OH})$ (2)/Mg-Al LDH Composite Film Formed on Mg Alloy AZ61. Materials 2018, 11, 1659.

(23) Kamiyama, N.; Panomsuwan, G.; Yamamoto, E.; Sudare, T.; Saito, N.; Ishizaki, T. Effect of treatment time in the $\mathrm{Mg}(\mathrm{OH}) 2 / \mathrm{Mg}$ $\mathrm{Al} \mathrm{LDH}$ composite film formed on Mg alloy AZ31 by steam coating on the corrosion resistance. Surf. Coat. Technol. 2016, 286, 172-177.

(24) Chen, J.; Song, Y.; Shan, D.; Han, E.-H. In situ growth of Mg-Al hydrotalcite conversion film on AZ31 magnesium alloy. Corros. Sci. 2011, 53, 3281-3288.

(25) Chen, J.; Song, Y.; Shan, D.; Han, E.-H. Influence of alloying elements and microstructure on the formation of hydrotalcite film on Mg alloys. Corros. Sci. 2015, 93, 90-99.

(26) Liu, X.; Zhen, Z.; Liu, J.; Xi, T.; Zheng, Y.; Guan, S.; Zheng, Y.; Cheng, Y. Multifunctional MgF2/Polydopamine Coating on Mg Alloy for Vascular Stent Application. J. Mater. Sci. Technol. 2015, 31, 733743.

(27) Mao, L.; Shen, L.; Chen, J.; Wu, Y.; Kwak, M.; Lu, Y.; Xue, Q.; Pei, J.; Zhang, L.; Yuan, G.; Fan, R.; Ge, J.; Ding, W. Enhanced bioactivity of $\mathrm{Mg}-\mathrm{Nd}-\mathrm{Zn}-\mathrm{Zr}$ alloy achieved with nanoscale $\mathrm{MgF} 2$ surface for vascular stent application. ACS Appl. Mater. Interfaces 2015, 7, 5320-5330.

(28) Chen, Y.; Zhao, S.; Liu, B.; Chen, M.; Mao, J.; He, H.; Zhao, Y.; Huang, N.; Wan, G. Corrosion-controlling and osteo-compatible $\mathrm{Mg}$ ion-integrated phytic acid (Mg-PA) coating on magnesium substrate for biodegradable implants application. ACS Appl. Mater. Interfaces 2014, 6, 19531-19543.

(29) Asl, V. Z.; Zhao, J. M.; Anjum, M. J.; Wei, S. X.; Wang, W.; Zhao, Z. J. The effect of cerium cation on the microstructure and anticorrosion performance of $\mathrm{LDH}$ conversion coatings on AZ31 magnesium alloy. J. Alloys Compd. 2020, 821, 153248.

(30) Kuang, J.; Ba, Z.; Li, Z.; Wang, Z.; Qiu, J.; et al. The study on corrosion resistance of superhydrophobic coatings on magensium. Appl. Surf. Sci. 2020, 501, 144137.

(31) Lin, J.; Hsia, C.; Uan, J. Characterization of Mg,Al-hydrotalcite conversion film on $\mathrm{Mg}$ alloy and $\mathrm{Cl}-$ and $\mathrm{CO} 32$ - anionexchangeability of the film in a corrosive environment. Scripta Mater. 2007, 56, 927-930.

(32) Tedim, J.; Kuznetsova, A.; Salak, A. N.; Montemor, F.; Snihirova, D.; Pilz, M.; Zheludkevich, M. L.; Ferreira, M. G. S. Zn-Al layered double hydroxides as chloride nanotraps in active protective coatings. Corros. Sci. 2012, 55, 1-4.

(33) Hu, H.-J.; Liu, X.-Y.; Ding, C.-X. Bioactive Porous and Nanostructured $\mathrm{TiO} 2$ Coating Prepared by Plasma Electrolytic Oxidation. J. Inorg. Mater. 2011, 26, 585-590.
(34) Ding, Z.; Qiao, Y.; Peng, F.; Xia, C.; Qian, S.; Wang, T.; Sun, J.; Liu, X. Si-doped porous $\mathrm{TiO} 2$ coatings enhanced in vitro angiogenic behavior of human umbilical vein endothelial cells. Colloids Surf., B 2017, 159, 493-500.

(35) Kusumbe, A. P.; Ramasamy, S. K.; Adams, R. H. Coupling of angiogenesis and osteogenesis by a specific vessel subtype in bone. Nature 2014, 507, 323-328.

(36) Xie, H.; Cui, Z.; Wang, L.; Xia, Z.; Hu, Y.; Xian, L.; Li, C.; Xie, L.; Crane, J.; Wan, M.; Zhen, G.; Bian, Q.; Yu, B.; Chang, W.; Qiu, T.; Pickarski, M.; Duong, L. T.; Windle, J. J.; Luo, X.; Liao, E.; Cao, X. PDGF-BB secreted by preosteoclasts induces angiogenesis during coupling with osteogenesis. Nat. Med. 2014, 20, 1270-1278.

(37) He, W.; Zhang, H.; Qiu, J. X. Osteogenic effects of bioabsorbable magnesium implant in rat mandibles and in vitro. $J$. Periodontol. 2020, DOI: $10.1002 /$ JPER.20-0162.

(38) Kawamura, N.; Nakao, Y.; Ishikawa, R.; Tsuchida, D.; Iijima, M. Degradation and Biocompatibility of AZ31 Magnesium Alloy Implants In Vitro and In Vivo: A Micro-Computed Tomography Study in Rats. Materials 2020, 13, 473.

(39) Peng, F.; Wang, D. H.; Tian, Y. X.; Cao, H. L.; Qiao, Y. Q.; Liu, $\mathrm{X}$. Y. Sealing the Pores of PEO Coating with $\mathrm{Mg}-\mathrm{Al}$ Layered Double Hydroxide: Enhanced Corrosion Resistance, Cytocompatibility and Drug Delivery Ability. Sci. Rep. 2017, 7, 8167. 